Robert Jakimowicz

(Akademia Ekonomiczna w Krakowie)

\title{
Spór o Wyspy Kurylskie w okresie prezydentury Władimira Putina
}

Sporu terytorialnego odziedziczonego przez Federację Rosyjską po Związku Radzieckim nie udało się rozwiązać po dzień dzisiejszy. Politycy Rosji i Japonii doskonale zdają sobie sprawę z tego, iż całkowita normalizacja wzajemnych stosunków nie będzie możliwa dopóty, dopóki spór ten nie zostanie rozwiązany. W związku z tym oba kraje znajdują się wciąż w ślepej uliczce, co uniemożliwia dynamiczny rozwój wzajemnych stosunków w różnych dziedzinach - szczególnie gospodarczej i społecznej. Pomimo dobrej woli obu stron, wiele okoliczności przemawia za tym, że status quo zostanie zachowany. W tym miejscu należy wspomnieć, iż stosunki japońsko-rosyjskie, od momentu podpisania między obu krajami pierwszego traktatu z 7 lutego 1855 r., zwanego Traktatem z Shimody, nigdy nie układały się po myśli obu stron. Można postawić tezę, że pojawiły się bariery obiektywne, które nie pozwalały ani wcześniej, ani później na normalny i wszechstronny rozwój obustronnych stosunków między obu państwami, jak np. miało to miejsce w przypadku Stanów Zjednoczonych czy krajów zachodnioeuropejskich. Nawet Polska w okresie międzywojennym miała bardzo dobre stosunki z Japonią, uwarunkowane oczywiście określonymi oczekiwaniami ze strony tego państwa ${ }^{1}$.

Obecny spór terytorialny jest wynikiem zajęcia przez wojska radzieckie w ostatnich dniach II wojny światowej wysp: Etorofu (zwanej przez Rosjan Iturup), Kunashir, Shikotan oraz wysp Habomai (wyspy leżą między japońską wyspą Hokkaido a Urup - w Japonii nazywa się je Terytoriami Północnymi, a w Rosji Południowymi Kurylami), które od nawiązania stosunków między obu państwami nie znajdowały się oficjalnie ani w granicach Rosji carskiej, ani w obrębie państwa Radzieckiego ${ }^{2}$. W okresie istnienia Związku Radzieckiego,

${ }^{1}$ Zob. m.in.: E. P ała s z-R u t kow s k a, Polityka Japonii wobec Polski 1918-1941, Nozomi, Warszawa 1998; E. P a ł a s z - R u t k o w s k a, A. T. R o m e r, Historia stosunków polsko-japońskich 1904-1945, Bellona, Warszawa 1990.

${ }^{2} \mathrm{~W}$ artykule drugim traktatu z Shimody została po raz pierwszy ustalona granica japońsko-rosyjska. Zgodnie z nim granica między obu państwami przebiegała na Kanale Uruppu. Wyspy znajdujące się na południe od Kanału Uruppu przypadły Japonii - są to wyspy, o które od 
a później Federacji Rosyjskiej obie strony odwoływały się w sporze do wielu porozumień, odmiennie je interpretując. Należy do nich zaliczyć przede wszystkim: wspomniany Traktat z Shimody z 1855 r., Traktat z Sankt Petersburga z 1875 r., Traktat pokojowy z Portsmouth z 1905 r., Moskiewski pakt o neutralności z 1941 r., Porozumienie jałtańskie z 1945 r., Traktat pokojowy z San Francisco z 1951 r., Deklarację październikową z 1956 r., japońsko-amerykański Traktat o wzajemnej współpracy i bezpieczeństwie z 1960 r., Wspólny komunikat radziecko-japoński z 1991 r. oraz japońsko-rosyjską Deklarację tokijską z 1993 r. Należy także przypomnieć o ważnych spotkaniach nieformalnych między prezydentem Borysem Jelcynem i premierem Ryutaro Hashimoto, które odbyły się w Krasnojarsku (1-2 listopada 1997 r.) i w kurorcie Kawana w Japonii (18-19 kwietnia 1998 r.), na których zapadły ważne ustalenia odnośnie do zawarcia traktatu pokojowego między obu państwami, a tym samym ostatecznego rozstrzygnięcia sporu terytorialnego ${ }^{3}$.

Przed wyznaczeniem Władmira Putina na następcę Borysa Jelcyna w grudniu 1999 r. (w marcu 2000 r. w wyborach prezydenckich Putin odnosi spektakularne zwycięstwo) stosunki japońsko-rosyjskie, z punktu widzenia sporu terytorialnego, możemy podzielić na dwa okresy. Pierwszy obejmuje czas od stycznia 1992 do października 1993, kiedy nie podejmowano działań w sprawie rozwiązania sporu terytorialnego. Drugi okres rozpoczęty Deklaracją tokijską z 1993 r. zakończył się z chwilą przekazania obowiązków prezydenta Rosji Władimirowi Putinowi w grudniu 1999 r. Można go podzielić na dwa etapy. Pierwszy trwał od październikowej Deklaracji tokijskiej do kwietniowej wizyty w 1996 r. premiera Ryutaro Hashimoto w Moskwie. Etap ten zapoczątkował proces rozwiązania sporu terytorialnego i przełamania wzajemnej nieufności. Drugi etap charakteryzował się intensyfikacją rozmów i budową wzajemnie przyjaznych stosunków. Prowadzone rozmowy były nieoficjalne (Krasnojarsk i Kawana), w związku z tym ustalenia obu polityków miały prawdopodobnie dla ich następców niewiążący charakter co postawiło ich w punkcie wyjścia, czyli w kontekście październikowej Deklaracji tokijskiej ${ }^{4}$. W tym miejscu należy przypomnieć, że rosyjski prezydent i japoński premier przeprowadzili rozmowy

kilkudziesięciu lat po II wojnie światowej toczy się spór. Zob. Traktat o torgovle, zakljuczennyj meżdu Rossiej i Japoniej v Simode 26 janvarja 1855 g. [u Japończyków był to dzień 7 lutego], [w:] Sbornik Dejstvujuszczich Traktatov' Konvencij i Soglaszenij, zakljuczennych Rossiej s' Drugimi Gosudarstvami i kasajuszczichsja razlicznych' woprosow' czastnogo meżdunarodnago prawa, t. 1, Sankt-Peterburg 1889, s. 24.

${ }^{3}$ Zob. R. J a k i m o w i c z, Japońsko-radziecki spór terytorialny, [w:] Prace z zakresu nauk politycznych, „Zeszyty Naukowe Akademii Ekonomicznej w Krakowie” 1992 [dalej: ZN AE Kraków], nr 358, s. 19-35; i d e m, Stanowisko ZSRR w sporze terytorialnym z Japoniq (19451991), [w:] Prace z zakresu nauk politycznych, ZN AE Kraków 1994, nr 424, s. 51-67; i d e m, Japońsko-rosyjski spór terytorialny po upadku Zwiqzku Radzieckiego, [w:] Prace z zakresu nauk politycznych, ZN AE Kraków 2000, nr 548, s. 33-45.

${ }^{4}$ R. J a k i m o w i c z, Japońsko-rosyjski spór terytorialny..., s. 33-45. 
w kwestii przynależności spornych wysp oraz stwierdzili, iż „,będą kontynuowane rozmowy w celu szybkiego zawarcia traktatu pokojowego na drodze rozwiązania wyżej wspomnianych kwestii, opierające się na czynnikach historycznych i prawnych, na opracowanych przez oba kraje dokumentach, a także zasadach praworządności i sprawiedliwości, aby w ten sposób w pełni znormalizować obustronne stosunki" ". Ponadto prezydent Jelcyn w imieniu rządu swojego kraju potwierdził, że Federacja Rosyjska, będąca spadkobiercą Związku Radzieckiego, zamierza honorować wszystkie porozumienia i traktaty, które zostały zawarte pomiędzy Związkiem Radzieckim i Japonią. Oznaczało to oficjalne honorowanie przez Rosję Wspólnej deklaracji radziecko-japońskiej z października 1956 r., w której wyraźnie stwierdzono, że po zawarciu traktatu pokojowego między obu państwami wyspa Shikotan i grupa wysp Habomai (łącznie traktowane jako dwie Wyspy Kurylskie) zostaną zwrócone Japonii ${ }^{6}$.

Po objęciu przez Władimira Putina urzędu prezydenta Rosji rozpoczął się kolejny etap stosunków rosyjsko-japońskich. Na początku był on nacechowany ze strony japońskiej zarówno olbrzymimi nadziejami, jak i obawami. Przede wszystkim postać Władimira Putina była wcześniej nieznana japońskim politykom, w związku z tym trudno było stwierdzić w jakim kierunku pójdzie polityka nowego rosyjskiego kierownictwa w skali globalnej, a w szczególności w stosunkach z Japonią. Co więcej, nawet politologowie japońscy przyznawali w publikacjach, że w sierpniu 1999 r., w chwili nieoczekiwanego mianowania Władimira Putina przez prezydenta Borysa Jelcyna na stanowisko premiera Rosji, nikt z kierowników resortów rządowych w Tokio nie miał jasnego wyobrażenia o tym, kim jest Putin, co sobą reprezentuje i jakie są jego poglądy na problemy polityki wewnętrznej i zagranicznej Rosji oraz problemy związane ze stosunkami rosyjsko-japońskimi ${ }^{7}$. Japońscy dziennikarze i politolodzy pospiesznie wyjaśniali przeszłość Putina, wyliczając instytucje, w których wcześniej pracował, a szczególnie jego służbową działalność w Komitecie Bezpieczeństwa ${ }^{8}$.

Polityków japońskich niepokoiła możliwość odrzucenia przez nowego prezydenta dotychczasowej polityki Jelcyna na rzecz pojednania i partnerstwa Rosji ze Stanami Zjednoczonymi i krajami Europy Zachodniej, a także odrodze-

${ }^{5}$ Tokijskaja deklaracja o rossijsko-japonskich otnoszenijach [dokument], „Problemy Dal'nego Vostoka" 1993, nr 5, s. 3-5; Iz Tokijskoj deklaracji w rossijsko japonskich otnoszsenijach ot 13 oktrjabrja 1993 g., [w:] W. I. Z i 1 a n o w, A. A. K o s z k i n, I. A. L a t y s z e w i in., Pusskie Kurily: isstorija i sowremennost'. Sbornik dokumentow po istorii formirowanija russko-japonskoj i sowetsko-japonskoj granicy, Moskwa 1995, s. 156-157.

${ }^{6}$ Sovmestnaja Deklaracija Sojuza Sovetskich Socjalisticzeskich Republik i Japonii-Moskwa 19 oktjabrja 1956 goda, ,Nowoje Wremija” [Wkladka - Dokumenty], 25 X 1956.

${ }^{7}$ I. L a t y s z e w, Rossija i Japonija. W tupike territorial'nogo spora 2000-2004, Instytut Wostokowedenija Rossijskoj Akademii Nauk, Algorytm, Moskwa 2004, s. 52-53.

${ }^{8}$ Ibidem, s. 53. 
nia byłej potęgi wojennej Rosji i ustanowienia ścisłych więzi sojuszniczych z Chińską Republiką Ludową .

Niewątpliwie politycy japońscy mieli także obawy o wcześniejsze próby Rosjan, zmierzające do oddzielenia ich od oczekiwań, związanych z negocjacjami w sprawie traktatu pokojowego zaplanowanego na $2000 \mathrm{r}$. W trakcie wizyty japońskiego premiera Keizo Obuchiego w Moskwie, w listopadzie 1998 r., strona rosyjska poszukiwała szerszej interpretacji traktatu pokojowego, w którym można byłoby uchylić się od umowy rozwiązania kwestii terytorialnej. Została wysunięta idea traktatu o przyjaźni i współpracy, pozwalającego uniknąć odniesienia się do sporu ${ }^{10}$. Z kolei w lutym 1999 r. rosyjski minister spraw zagranicznych, Igor Iwanow, w udzielonym wywiadzie oświadczył, że japońskie żądanie traktatu pokojowego jest ,anachronizmem” i wyraził pragnienie zawarcia traktatu o pokoju, przyjaźni i współpracy. Według Iwanowa, traktat o przyjaźni i kwestia terytorialna stanowią dwie oddzielne sprawy, które nie powinny wpływać na integralność terytorialną Rosji11. Minister Iwanow wyjaśnił swojemu japońskiemu partnerowi, Masahiko Komurze, że zawarcie

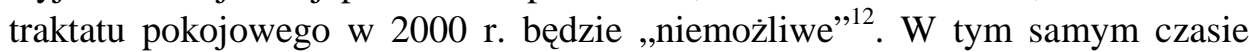
rosyjski ambasador w Tokio, Aleksander Panow, nakłaniał Japończyków do „realizmu” i szczerego wyjaśnienia tych zagadnień, japońskiemu społeczeństwu, bez tworzenia iluzji związanych z szybkim rozwiązaniem kwestii terytorialnej ${ }^{13}$.

W nowej sytuacji ówczesny ambasador Japonii w Moskwie, Minoru Tamba, opublikował w grudniu 2000 r. w czasopiśmie „Gaiko Forum” artykuł pt. $O$ rozwój wielopoziomowych stosunków japońsko-rosyjskich. Wyraźnie powiązał japońską pomoc gospodarczą dla Rosji z gotowością tego państwa do wyjścia naprzeciw „sprawiedliwym” pretensjom Japonii, związanym z żądaniem zwrotu czterech Wysp Kurylskich, co umożliwiłoby podpisanie traktatu pokojowego ${ }^{14}$. Należy podkreślić, że w Japonii występuje bezwarunkowe poparcie wszystkich ekspertów, komentatorów i polityków dla żądań zwrotu spornych wysp Japonii, bez względu na ich różnice w poglądach na inne kwestie japońskiej polityki zagranicznej. Natomiast takiej jedności w obronie spornych wysp nie ma w Rosji. Możemy znaleźć zarówno przeciwników, jak i zwolenników terytorialnych ustępstw wobec Japonii, także w kręgu prezydenta Władimira Putina ${ }^{15}$. Co więcej, prof. Igor Latyszew, jeden z głównych naukowych współpracowników

\footnotetext{
${ }^{9}$ Ibidem, s. 54.

${ }^{10}$ L. B u s z y ń s k i, Russia and Northeast Asia: aspirations and reality, „The Pacific Review" 2000, Vol. 13, No. 3, s. 407.

${ }^{11}$ Ibidem.

${ }^{12}$ Ibidem.

${ }^{13}$ Ibidem.

${ }^{14}$ I. L a t y s z e w, op. cit., s. 62-63.

${ }^{15}$ Ibidem, s. 63-64.
} 
Instytutu Orientalistyki Rosyjskiej Akademii Nauk, zaliczający się do obozu patriotów rosyjskich, wręcz oskarża na stronach swej książki część rosyjskich publicystów i pracowników naukowych, o przejście jeszcze w latach dziewięćdziesiątych na stronę japońską, co miało wyrażać się w popieraniu japońskich żądań terytorialnych. Oczywiście, jak Latyszew podkreśla, za to poparcie otrzymywali oni szczodre honoraria od japońskich wydawnictw i różnego typu instytucji japońskiego funduszu, szeroko rozwijającego swoją działalność w Moskwie pod kontrolą ministerstwa spraw zagranicznych Japonii ${ }^{16}$. Jedną ze wspomnianych osób jest Borys Slawinski, którego obszerna monografia zatytułowana ZSRR i Japonia - na drodze ku wojnie: historia dyplomatyczna, 1937-1945 ${ }^{17}$ została przetłumaczona na język japoński i w 1999 r. była sprzedawana w dużym nakładzie w Tokio. Należy jednak dodać, że w japońskim wydaniu tytuł brzmiał inaczej, a mianowicie $N a$ drodze ku japońsko-radzieckiej wojnie. Od Chatchyn Got do okupacji Wysp Kurylskich ${ }^{18}$. Wyraz ,okupacja” jest tu oczywiście słowem o kluczowym znaczeniu i sugeruje niejednoznacznie, że Związek Radziecki stał się okupantem spornych wysp, a w związku z tym japońskie żądania są jak najbardziej uzasadnione.

W kolejnej publikacji z 2000 r., pracy zbiorowej pod redakcja profesora Uniwersytetu Howei, Nobuo Shimotae, zatytułowanej Terytoria Pótnocne: 80 pytań $i$ odpowiedzi, jeden $\mathrm{z}$ rozdziałów został napisany przez Konstantina Sarkisowa, byłego kierownika Katedry Japonii Instytutu Orientalistyki Rosyjskiej Akademii Nauk, mieszkającego w tym czasie w Japonii. W rozdziale tym Sarkisow udzielał japońskim dyplomatom rad, jak należałoby realizować zamierzenia związane z Kurylami w warunkach nasilania się oporu wobec tych żądań ze strony społeczeństwa rosyjskiego. Między innymi doradzał Japończykom, by związać Rosję prawnie sformułowaną umową dotyczącą wspólnego ekonomicznego zagospodarowania południowych Kuryli. Sarkisow uważał, że stworzyłoby to przesłanki do rozwiązania w przyszłości sporu terytorialnego obu krajów, z korzyścią dla Japonii i stopniowego uzyskania przez wyspy japońskie suwerenności ${ }^{19}$.

Następnie Latyszew w swoich rozważaniach zaznacza, że w ostatnich latach w Japonii nie zostały opublikowane ani książki, ani artykuły prasowe tych rosyjskich politologów-japonistów, którzy przeprowadzali analizę stosunków rosyjsko-japońskich z pozycji obrony narodowych interesów Rosji i sprzeciwiali się japońskim żądaniom dotyczącym Kuryli ${ }^{20}$.

${ }^{16}$ Ibidem, s. 64-65.

${ }^{17}$ B. N. S law inskij, SSSR i Japonija - na puti $k$ wojne: diplomaticzeskaja istorija, 1937-1945 gg., Moskwa 1999.

${ }^{18}$ I. L a t y s z e w, op. cit., s. 65.

${ }^{19}$ Ibidem, s. 65-66.

${ }^{20}$ Ibidem, s. 67. 
Tymczasem władze japońskie, chciały, aby jak najszybciej zostało wyjaśnione stanowisko prezydenta Putina w sprawie spornych wysp. Okazją ku temu miała być wizyta prezydenta Rosji w Tokio. Tymczasem 10 lutego 2000 r. przybył do Tokio rosyjski minister spraw zagranicznych, Igor Iwanow, który odbył spotkanie z premierem Keizo Obuchi i przekazał mu osobisty list prezydenta Putina. W liście zostało potwierdzone utrzymanie polityki Rosji, zakładającej „twórcze partnerstwo” z Japonią. W tym czasie odbyła się również rozmowa telefoniczna między przywódcami obu krajów, w trakcie której premier Obuchi nie omieszkał zaprosić prezydenta Putina do złożenia wizyty w Japonii $^{21}$. Jednak w kwietniu 2000 r. zmarł premier Obuchi, którego zastapił konserwatywny polityk Yoshiro Mori. Po upływie kilku tygodni premier Mori zwrócił się do Moskwy z wezwaniami dotyczącymi przyjazdu prezydenta Rosji do Japonii celem zakończenia rozmów w sprawie rosyjsko-japońskiego „,traktatu pokojowego". Z punktu widzenia Japonii, zawarcie „traktatu pokojowego" wiązało się z rozstrzygnięciem sporu terytorialnego, tj. powrotem wszystkich czterech wysp, przy czym przewidywano, że w pierwszej fazie, po podpisaniu traktatu przez obie strony, Japończycy zarządzaliby dwoma wyspami - Shikotan i grupa Wsyp Habomai, a dwie większe wyspy - Kunshir i Iturup przeszłyby w japońskie ręce w późniejszym czasie ${ }^{22}$. W Kawanie, w kwietniu 1998 r., gdzie doszło do spotkania prezydenta Jelcyna i premiera Hashimoto, strona rosyjska zaakceptowała w zasadzie japońską suwerenność. Jednakże japońskie stanowisko rozdzielało suwerenność od posiadania wysp. Rosjanie akceptowaliby japońską suwerenność, podczas gdy wyspy pozostawałyby w ich posiadaniu do momentu ostatecznego ich transferu na rzecz Japonii. Japończycy naciskali na Putina, aby zaakceptował rozwiązanie z Kawany przed swoją wizytą w Japonii we wrześniu 2000 r. i oczekiwali, że jego wizyta przyniesie postęp ${ }^{23}$.

Przed pierwszą wizytą w Japonii prezydent Władimir Putin wzmocnił swoją władzę w kraju, co dało mu lepszą pozycję do odpierania japońskich żądań i wysuwania własnych propozycji. Aby umocnić swoje stanowisko, musiał przeprowadzić wewnętrzne reformy. Należy tu wyjaśnić, że po odejściu ze stanowiska prezydenta Jelcyna pozostały po okresie rządzenia elementy rosyjskiego federalizmu, które sprowadzały się do równowagi władzy w relacjach centrum - region. Przyczyniło się to do znacznego wzrostu autorytetu m.in. władz sachalińskich w sprawach związanych ze spornymi Wyspami Kurylskimi. W przeprowadzeniu reform, które wyraźnie zmniejszyły skuteczność tzw. „sachalińskiego czynnika”, pomogły Putinowi jego twarde stanowisko wobec Czeczenii, wzrost światowych cen ropy naftowej, który przyniósł zwiększenie

${ }^{21}$ Ibidem, s. 69.

${ }^{22}$ Ibidem, s. 71-72.

${ }^{23}$ L. B u s z y ń s k i, Oil and territory in Putin's relations with China and Japan, ,The Pacific Review", September 2006, Vol. 19, No. 3, s. 295. 
dochodów państwa oraz dobra współpraca z rosyjską Dumą. Czynniki te dały wysoki wskaźnik poparcia publicznego dla nowego prezydenta. Istota reform polegała na przywróceniu federalnej kontroli nad zbyt samodzielnymi regionami Rosji. Pierwsza reforma była związana z dekretem z maja 2000 r. i likwidowała przeszło osiemdziesięciu przedstawicieli prezydenckich $\mathrm{w}$ osiemdziesięciu dziewięciu regionach Rosji zastępując ich siedmioma, którzy mieli być odpowiedzialni za geograficzne granice federalnych regionów. Druga dotyczyła izby wyższej parlamentu narodowego, Rady Federacji, która w pełni weszła w życie 1 stycznia 2002 r. Przyczyniła się ona do erozji wpływów gubernatorów. Trzecia reforma dała władzom federalnym możliwość usuwania gubernatorów, którzy łamią prawo oraz władzę rozwiązywania regionalnych zgromadzeń ustawodawczych, które przyjmują prawa sprzeczne z konstytucją i odmawiają poprawiania ich po ostrzeżeniach sądu ${ }^{24}$.

Stanowisko Putina na temat spornych Terytoriów Północnych zmieniło się, czego powodem było wspomniane umocnienie władzy prezydenckiej. W trakcie pierwszych sześciu miesięcy urzędowania sygnalizował, że przyjmie bezkompromisowe stanowisko $\mathrm{w}$ sprawie sporu terytorialnego. Ta bezkompromisowość została zademonstrowana podczas przerwy w podróży na Sachalinie w drodze do Japonii we wrześniu 2000 r. Przyznając, że istnieje problem terytorialny i wyrażając gotowość do zbadania go, Putin oświadczył, że „Rosja nie będzie oddawała swojego terytorium komukolwiek" ${ }^{\text {"25 }}$. Klarowność tego oświadczenia miała wyciszyć lokalne niepokoje związane z możliwymi ustępstwami terytorialnymi, a włączenie gubernatora Sachalinu, Farkhutdinowa, w skład delegacji na czas wizyty $\mathrm{w}$ Japonii podkreśliło wrażliwość prezydenta na „czynnik sachaliński”.

Pierwsza oficjalna wizyta w Japonii prezydenta Władmira Putina odbyła się w dniach 3-5 września 2000 r. Prezydent Federacji Rosyjskiej przeprowadził rozmowy z premierem Mori, był obecny na oficjalnym obiedzie u cesarza Akihito i spotkał się z delegacją seniorów japońskiego biznesu. Chociaż obaj liderzy zobowiązali się do bliższej współpracy w dziedzinie regionalnego bezpieczeństwa i spraw gospodarczych, nie udało się im osiagnąć porozumienia w sprawie spornych wysp ${ }^{26}$. W rozmowie ze swoim japońskim partnerem, który odwoływał się do ustaleń Hashimoto - Jelcyn prezydent Putin podkreślił, że w oświadczeniach byłych przywódców mówiło się tylko o zamiarze obu stron, by „podjąc się wysiłków” w celu podpisania traktatu w wyznaczonym czasie.

${ }^{24} \mathrm{~B} . \mathrm{W}$ i $11 \mathrm{i}$ a m s, Federal-regional relations in Russia and the Northern Territories dispute: the rise and demise of the 'Sakhalinfactor', http://taylorandfrancisw.metapress.com (stan z 19.09.2006).

${ }^{25}$ B. W i 11 i a m s, op. cit., za G. W a s il' e w, I. Gornost a ew a i L. Kas 'j a n, Prebywanie prezidenta Rossii Wladimira Putina na Sachaline, „Gubernskie wedomosti”, 5 sentjabrja 2000, s. 1.

${ }^{26}$ Keesing's Record of World Events, ,News Digest”, September 2000, s. 43750. 
Ponadto odrzucił japońskie oddzielenie suwerenności od posiadania i zaproponował kompromis oparty na deklaracji z 1956 r., zgodnie z którym dwie wyspy $\mathrm{z}$ czterech będą oddane Japonii ${ }^{27}$. Kompromis ten został uznany przez Japończyków za pozytywny krok. Jednak japońska i rosyjska interpretacja porozumienia z 1956 r. różnią się znacznie. Rosjanie twierdzą, że porozumienie to jest „ostatecznym rozwiązaniem” - Rosja jest zobligowana jedynie do zwrotu dwóch wysp. Strona japońska oświadczyła, że deklaracja z 1956 r. oznacza początkowy zwrot dwóch wysp, po którym nastąpi przekazanie pozostałych dwóch. Minister spraw zagranicznych Yohei Kono stwierdził, że było to zrozumiałe w czasie jej projektowania $^{28}$.

Podczas gdy Putin uznał prawomocność wspólnej deklaracji z 1956 r., w trakcie rozmów z japońskim premierem Yoshiro Mori przyjął radziecką strategię negocjacji, pochodząca $\mathrm{z}$ lat siedemdziesiątych, mającą na celu opóźnienie rozwiązania sporu terytorialnego przez proponowanie przejściowego Traktatu o pokoju, przyjaźni i współpracy ${ }^{29}$. Była to propozycja alternatywna wobec planu Hashimoto. Według zamysłu rosyjskiego kierownictwa, wejście w życie tego traktatu powinno poprzedzać podpisanie traktatu pokojowego przez oba kraje, pod tym warunkiem, że rosyjsko-japoński spór terytorialny będzie odłożony na przyszłość, tj. do czasu, kiedy umocnią się dobrosąsiedzkie przyjazne stosunki między obu krajami ${ }^{30}$.

Oznaczało to, że wcześniejsze ustalenia Borysa Jelcyna z premierem Ryutaro Hashimoto, przewidujące zawarcie traktatu pokojowego do końca 2000 r., okazały się nierealne. Oczekiwania obu stron były rozbieżne. Prezydent Putin widział swoje zadanie w omówieniu perspektyw maksymalnego rozszerzenia rosyjsko-japońskiej współpracy gospodarczej, ponieważ skala tej współpracy była niewystarczająca w porównywaniu z innymi krajami. Na przykład w 2000 r. wartość rosyjsko-japońskich obrotów handlowych wyniosła zaledwie 5 mld 124 mln USD (1999 r. - 4 mld 250 mln USD), gdy natomiast japońsko-chińskich - 85 mld 512 mln USD i japońsko-amerykańskich - $216 \mathrm{mld} 523 \mathrm{mln}$ USD $^{31}$. Perspektywy rozszerzenia współpracy gospodarczej prezydent Putin przedstawił na spotkaniu z japońskimi biznesmenami. Główny projekt dotyczył sprzedaży Japonii rosyjskiej energii elektrycznej (w ilości 25,5 mld kwt rocznie), która miałaby być przekazywana czterema podwodnymi kablami przerzuconymi przez Cieśninę La Perouse'a, z Sachalinu na Hokkaido. Jednak realizacja podobnego projektu stanęła natychmiast pod znakiem zapytania, gdy kilka

${ }^{27}$ L. B u s z y ń s k i, Oil and territory..., s. 295.

${ }^{28}$ Ibidem, s. 296.

${ }^{29}$ B. W i 11 i a m s, Federal-regional relations..., s. 2.

${ }^{30}$ I. L a t y s z e w, op. cit., s. 80-81, „The Japan Times”, 6 September 2000.

${ }^{31} \mathrm{Na}$ temat obrotów handlowych Japonii z Rosją, ChRL i Stanami Zjednoczonymi za lata 1992-2004 zob. Direction of Trade Statistics Yearbook, International Monetary Found, Washington (Annual 1997, 2002, 2005), s. 270-271, 278-279, 276-277. 
miesięcy później, zimą 2000/2001, nastąpił katastroficzny kryzys energetyczny na rosyjskim Dalekim Wschodzie ${ }^{32}$.

Niemniej jednak zagospodarowanie i eksploatacja bogactw naturalnych na rosyjskim Dalekim Wschodzie i na Syberii była brana pod uwagę przez obie strony, kierujące się odmiennymi motywami. Japonia uznawała tego typu współpracę gospodarczą za ważny środek do rozwiązana w przyszłości problemu terytorialnego. Co więcej, rozwój gospodarczy spornych wysp, w którym znaczny udział przypadłby Japończykom, stopniowo doprowadziłby do zniesienia dotychczasowych różnic $\mathrm{w}$ porównaniu $\mathrm{z}$ rozwiniętym terytorium Japonii, co miałoby w przyszłości ułatwić zarówno prawny, jak i formalny ich zwrot państwu japońskiemu ${ }^{33}$.

Biorąc pod uwagę te, a także inne przesłanki, premier Mori nie był zainteresowany powstaniem rozdźwięków i sporem z rosyjskim prezydentem, podobnie Putin chciał uniknąć jakichkolwiek tarć. Spotkanie obu przywódców zakończyło się podpisaniem wspólnego memorandum o ich obopólnej gotowości do kontynuowania rozmów dwustronnych w celu uniknięcia istotnych rozbieżności i szybszego zawarcia traktatu pokojowego ${ }^{34}$. Konkludując, spotkanie to nie stanowiło przełomu i rozczarowało stronę japońską. Prezydent Putin, godząc się na przyszłe rozmowy dotyczące traktatu pokojowego, nie zajął stanowiska patriotów rosyjskich, które sprowadzało się do odrzucenia wszelkich kompromisów.

Polityczne rezultaty, jakie zostały osiągnięte we Wspólnym oświadczeniu z 5 września 2000 r. były następujące:

- utworzenie Komisji do spraw zawarcia traktatu pokojowego na poziomie ministrów spraw zagranicznych;

- utworzenie podkomisji do przeprowadzenia podziału granicy, w ramach której kontynuowane są rozmowy;

- podpisanie Programu japońsko-rosyjskiej współpracy w dziedzinie rozwoju wspólnej gospodarczej działalności na wyspach Iturup, Kunashir, Shikotan i Habomai;

- zgoda na kontynuację rozmów z zastrzeżeniem, aby opierając się na wszystkich osiagniętych do tej pory umowach, w tym Deklaracji tokijskiej o stosunkach japońsko-rosyjskich z 1993 r. i Deklaracji moskiewskiej o ustanowieniu twórczego partnerstwa między Japonią i Federacją Rosyjską z 1998 r., wypracować traktat pokojowy ,drogą rozwiązania kwestii o przynależności wysp Iturup, Kunashir, Shikotan i Habomai" 35 .

W tym miejscu należy podkreślić, że niezgadzając się z powyższymi zapisami, nie popierają również tych, które znalazły się we Wspólnej deklaracji

${ }^{32}$ I. L a t y s z e w, op. cit., s. 76-77.

${ }^{33}$ Ibidem, s. 78-79.

${ }^{34}$ Ibidem, s. 81.

${ }^{35}$ Russkie Kurily. Istorija i sowremennost'. Sbornik dokumentow po istorii formirowanija russko-japonskoj i sowetsko-japonskoj granicy, Algorytm, Moskwa 2002, s. 178-180. 
październikowej z 1956 r., które były i są dla nacjonalistów rosyjskich nie do przyjęcia. Odpowiedzialność za tego rodzaju deklarację, wspominającą o traktacie pokojowym, została zrzucona przez nich na rosyjskie ministerstwo spraw zagranicznych. Niemniej jednak patrioci rosyjscy dostrzegają jakościową różnicę na niekorzyść Rosji, która pojawiła się we Wspólnym oświadczeniu w kwestii problemu traktatu pokojowego. Jak podkreślają, w odróżnieniu od Wspólnej deklaracji z 1956 r., w której poruszono kwestię dwóch wysp (Habomai i Shikotan), w obecnym dokumencie za przykładem dokumentów z czasów Gorbaczowa i Jelcyna, w charakterze obiektów sporu wspomina się z jakiegoś powodu cztery wyspy, wliczając w nie Kunashir i Iturup (Etorofu) ${ }^{36}$. Fakt ten można skomentować następująco: 19 października 1956 r. została podpisana Wspólna deklaracja, a nie traktat pokojowy, ponieważ przedstawiciele obu krajów nie rozwiązali ostatecznie sporu terytorialnego. Jednym z powodów było wmieszanie się Stanów Zjednoczonych do rokowań japońsko-radzieckich ${ }^{37}$. Ówczesny minister spraw zagranicznych Japonii, Mamoru Matsumoto, w trakcie swojej wizyty w Moskwie 20 września 1956 r. uzyskał od strony radzieckiej zapewnienie, że nawet po normalizacji stosunków będą kontynuowane negocjacje dotyczace zawarcia traktatu pokojowego, obejmujące kwestie terytorialne ${ }^{38}$. Dzięki tej obietnicy udało się podpisać wówczas wspomnianą Wspólną deklarację, dzięki której zakończył się stan wojny między obu krajami. Uzgodniono w niej ponadto oddanie wysp Shikotan i Habomai Japonii, ale po podpisaniu traktatu pokojowego. W związku z tym użycie sformułowania „z jakiegoś powodu" jest co najmniej dwuznaczne.

Jednak unikanie przez obie strony konfrontacji w stosunkach oficjalnych było niewątpliwie przyczyną poprawy wzajemnych stosunków. W listopadzie 2000 r. premierzy obu krajów sugerowali, że spotkają się wkrótce ponownie i pewna liczba porozumień zostanie podpisana. Japonia i Rosja zgodziły się 3 listopada, aby dążyć do „nowego zbliżenia” i rozwiązać spór dotyczący suwerenności Wysp Kurylskich ${ }^{39}$. Ponadto 24 listopada tego roku oba kraje podpisały wspólne memorandum na temat praw do połowów na wodach wokół spornych wysp. Natomiast 28 listopada dyrektor generalny Japońskiej Agencji Obrony, Kazuo Torashima, spotkał się z rosyjskim ministrem obrony, Igorem Siergiejwem i podpisał porozumienie o współpracy w dziedzinie obrony, które przewidywało wspólne badania i ćwiczenia ratownicze na morzu ${ }^{40}$.

Na początku 2001 r., stanowisko Putina w sprawie spornych terytoriów zaczęło się zmieniać. Podczas rozmów z premierem Mori w Irkucku (w mar-

${ }^{36}$ I. L a t y s z e w, op. cit., s. 82.

${ }^{37}$ Zob. R. J a k i m o w i c z, Japońsko-radziecki spór terytorialny, s. 30-31.

${ }^{38}$ Keesing's Contemporary Archives z 10-17 XI 1956 r., Vol. 10, s. 15 196; Warerea no Hoppo Ryodo, Gaimusho Daijin Kanbo Kokukai Kohoka, Tokyo 1980, s. 12-13.

${ }^{39}$ Keesing's Record of World Events, News Digest for November 2000, s. 43863.

${ }^{40}$ Ibidem. 
cu 2001 r.) zgodził się formalnie uznać prawomocność Wspólnej deklaracji z 1956 r. Stanowisko to zostało zawarte w tzw. Deklaracji irkuckiej. Zgoda ta oznaczała, że po raz pierwszy strona rosyjska uznała prawny związek Wspólnej deklaracji, który został potwierdzony w obustronnie napisanym porozumieniu, czego nie uczynili ani Michaił Gorbaczow, ani Borys Jelcyn ${ }^{41}$. Obaj przywódcy zaakceptowali zwrot dwóch wysp bez wyjaśnienia losu dwóch pozostałych. Igor Iwanow powiedział, że z chwilą uprawomocnienia Deklaracji październikowej z 1956 r. Rosja jest gotowa do negocjacji w sprawie traktatu pokojowego, a następnie jako „gest dobrej woli” zostanie dokonany transfer dwóch wysp do $\mathrm{Japonii}^{42}$.

W Tokio zgoda prezydenta Rosji została odczytana jako zaakceptowanie kompromisowego rozwiązania sporu o południowe Wyspy Kurylskie. Potwierdzeniem tego stanowiska mogło być dążenie władz rosyjskich do stworzenia w kraju sprzyjającej atmosfery wokół porozumienia przewidującego możliwość ustępstw terytorialnych. Władze regionalne zostały zawczasu o nich ostrzeżone. W lutym 2002 r. zostały wysłane listy do gubernatorów i regionalnych zgromadzeń ustawodawczych, podkreślających prawomocność Wspólnej deklaracji z 1956 r. Tym samym administracja prezydenta Putina dokonała kolejnego kroku, którego nikt nie uczynił wcześniej w krótkiej historii Federacji Rosyjskiej po upadku Związku Radzieckiego. Po raz pierwszy władze federalne otwarcie zadeklarowały politycznym elitom Sachalinu gotowość do przekonania Japonii dwóch spornych wysp. Informacja zawarta w listach nie była całkowitą niespodzianką dla urzędników sachalińskich, którzy już wcześniej znali intencje rządu federalnego dotyczące przekazania spornych ziem Chinom (we wschodnim regionie granicznym), wbrew przeciwnemu stanowisku elit politycznych w Chabarowsku, utrzymujących rosyjską kontrolę nad tymi terytoriami ${ }^{43}$. W tym miejscu należy wspomnieć, że porozumienie irkuckie wywołało krytykę po obu stronach.

Ze strony rosyjskiej gubernator Sachalinu Igor Fakhutdinow i deputowani otwarcie zaprotestowali, oświadczając, że wyspy są „niezbywalnym” rosyjskim terytorium. Federalna Duma (Parlament) przeprowadziła 13 marca 2002 r. przesłuchania na temat tej kwestii, zorganizowane przez Komisje do Spraw Bezpieczeństwa, Spraw Międzynarodowych i Geopolityki. Parlamentarzyści doszli do wniosku, że nie ma prawnych podstaw do przekazania wysp Japonii i że traktat pokojowy kosztem rosyjskiego terytorium jest ofiarą nie do przyjęcia. Przewodniczący Komisji do Spraw Bezpieczeństwa, Aleksander Burow, powiedział, że Japonia nie ma prawa do tych wysp ${ }^{44}$.

\footnotetext{
${ }^{41}$ B. W i 11 i a m s, Federal-regional relations..., s. 2.

${ }^{42}$ L. B u s z y ń s k i, Oil and territory..., s. 297.

${ }^{43}$ B. W i 11 i a m s, Federal-regional relations..., s. 2.

${ }^{44}$ L. B u s z y ń s k i, Oil and territory..., s. 297.
} 
Z kolei w Japonii premier Mori został skrytykowany w parlamencie za swoją gotowość do zaakceptowania zwrotu jedynie dwóch wysp i za wyrażenie zgody na traktat pokojowy przed zwrotem wszystkich wysp. W rezultacie Japończycy ponownie wyraźnie potwierdzili swoje żądanie odzyskania wszystkich wysp, szczególnie po tym, jak Junichiro Koizumi został premierem w kwietniu 2001 r. Nowy premier domagał się uznania przez Rosję suwerenności Japonii nad tymi terytoriami za konieczny warunek negocjacji, dotyczących traktatu pokojowego, który później zmodyfikował ${ }^{45}$. W lutym 2002 r. japońskie Ministerstwo Spraw Zagranicznych upierało się raczej przy równoległych, a nie oddzielnych negocjacjach z Rosjanami, aby zapobiec nieporozumieniom związanym $\mathrm{z}$ ich intencjami.

Tymczasem w marcu 2002 r. wybuchł skandal związany z wykorzystywaniem wpływów znanego polityka, Muneo Suzuki, który 19 czerwca tego roku został aresztowany na podstawie oskarżeń o korupcję. W kwietniu 2002 r. nowo mianowana minister spraw zagranicznych, Yoriko Kawaguchi, zaczęła domagać się od Rosji uznania japońskiej suwerenności nad wszystkimi wyspami, przy okazji zarzucając rosyjskiemu ministrowi spraw zagranicznych nieodpowiednie informowanie dziennikarzy $\mathrm{w}$ tej kwestii ${ }^{46}$. Reprezentując od poprzedników odmienne stanowisko, podjęła się próby wyeliminowania wpływów Suzukiego w ministerstwie. W tym celu usunęła jego bliskich przyjaciół Kazuhiko Togo, byłego szefa Biura Europejskiego i ówczesnego ambasadora w Holandii oraz Masaru Sato, urzędnika i analityka od spraw Rosji ${ }^{47}$. Byli oni autorami porządku dziennego negocjacji premiera Mori z Rosjanami na podstawie koncepcji dwa plus dwa, o której Suzuki wspomniał już w marcu 2001 r. rosyjskiemu zastępcy ministra spraw zagranicznych, Loszjukowi, podczas jego pobytu w Tokio. Należy podkreślić, że Suzuki stał się wcześniej kluczową postacią w formułowaniu japońskiej polityki, dotyczącej sporu terytorialnego. Miał on duży wpływ w ministerstwie spraw zagranicznych, przewodniczył komisji parlamentarnej do spraw regulaminu i administracji oraz był jednym z kluczowych członków w komisji spraw zagranicznych. Pochodził z okręgu wyborczego Nemuro we wschodniej części Hokkaido, znajdującej się naprzeciw spornych wysp. Jego głównym celem była realizacja projektów budowlanych na tych wyspach, co przyniosłoby wymierne korzyści towarzystwom działającym w jego okręu. W związku z tym Suzuki od wielu lat wywierał nacisk na urzędników Ministerstwa Spraw Zagranicznych, aby zaprzestali poszukiwania sposobu natychmiastowego powrotu spornych wysp, a zwrócili uwagę na rozwój bliższych stosunków gospodarczych z Rosją. Od 1997 r. opowiadał się za jedną z opcji Ministerstwa Spraw Zagranicznych, znaną jako zbliżenie „w dwóch krokach”. Pierwszy

\footnotetext{
${ }^{45}$ Ibidem.

${ }^{46}$ Ibidem.

${ }^{47}$ Ibidem.
} 
krok oznaczał zwrot dwóch mniejszych wysp, a drugi - dwóch większych, przy czym ten drugi był mglisty i nigdy nie został wyraźnie określony ${ }^{48}$.

W styczniu 2003 r., po półtora roku sprawowania urzędu, premier Junichiro Koizumi po raz pierwszy udał się z oficjalną wizytą do Moskwy. 10 stycznia odbyło się spotkanie na szczycie przywódców obu krajów, na którym przeprowadzono dyskusję nad długoletnim sporem terytorialnym oraz nad japońskimi propozycjami dotyczącymi rurociagu naftowego Syberia-Pacyfik. Jednak spotkanie w dużej części zostało zdominowane przez dyskusje o kryzysie spowodowanym przez ostatnie zmiany w polityce nuklearnej Korei Północnej, co nie sprzyjało większemu postępowi rozmów na temat sporu terytorialnego. Ponadto kwestia suwerenności wysp była brana pod uwagę coraz poważniej przez premiera Koizumiego w związku $\mathrm{z}$ podniesieniem wskaźnika jego popularności ${ }^{49}$. Generalnie rezultatem spotkania było podpisanie przez premiera Koizumiego i prezydenta Putina planu działań, dotyczącego rozwoju więzi gospodarczych, w tym współpracy związanej z energią ${ }^{50}$.

Jeśli chodzi o główne płaszczyzny działań określone w Planie, to dotyczyły one pogłębienia dialogu politycznego, rozmów na temat traktatu pokojowego, współpracy na arenie międzynarodowej, współpracy w dziedzinie stosunków handlowo-gospodarczych, rozwoju więzi w dziedzinie obronnej, rozwoju więzi kulturalnych i wymiany między obywatelami obu krajów ${ }^{51}$. Jak możemy zauważyć, jedna z wymienionych płaszczyzn, dotyczyła rozmów na temat traktatu pokojowego. Zwrócono uwagę, że został stworzony mechanizm rozwiązania tej skomplikowanej kwestii, jakim była Wspólna komisja rosyjsko-japońska do spraw zawarcia traktatu pokojowego, na której czele stanęli ministrowie spraw zagranicznych obu krajów. W jej ramach zostały powołane podkomisje do wydzielenia granicy i wspólnej działalności handlowej ${ }^{52}$. Poruszone zostały też inne kwestie: prowadzenie licznych dwustronnych forów i seminariów na temat spornych wysp, dyskusje parlamentarzystów z obu krajów (co miało doprowadzić do obniżenia emocji i wyeliminowania uprzedzeń) czy pogłębienie i rozszerzenie wymiany bezwizowej między mieszkańcami spornych wysp i japońskimi obywatelami. Od 1991 r. wymiana ta objęła 10 tysięcy obywateli z Rosji i Japonii ${ }^{53}$.

Kwestię traktatu pokojowego podkreślono również we wspólnym oświadczeniu obu przywódców z 10 stycznia: ,pragnąc ostatecznego przezwyciężenia trudnej spuścizny przeszłości w stosunkach dwustronnych i otwarcia nowych

${ }^{48}$ Ibidem, s. 296.

${ }^{49}$ Keesing's Record of World Events, News Digest for January 2003, s. 45189.

${ }^{50} \mathrm{~W}$. P a w $1 \mathrm{j}$ a t e n k o, Locmanskaja karta rossijsko-japonskich otnoszenij, „Problemy Dalniego Wostoka" 2003, nr 2, s. 22.

${ }^{51}$ Rossijsko-japonskij plan dejstwij, „Problemy Dalniego Wostoka” 2003, nr 2, s. 8-20.

${ }^{52}$ Ibidem.

${ }^{53}$ Ibidem. 
horyzontów dla szerokiego partnerstwa rosyjsko-japońskiego, potwierdzając zdecydowanie na drodze energicznych rokowań dotyczących możliwości szybszego zawarcia traktatu pokojowego w kwestii przynależności wysp Iturup [Etorofu - R.J.], Kunashir, Shikotan i Habomai i osiagnięcia w ten sposób pełnej normalizacji stosunków dwustronnych na podstawie zawartych do chwili obecnej umów, w tej liczbie Wspólnej deklaracji ZSSR i Japonii z 1956 r., Deklaracji tokijskiej o stosunkach japońsko-rosyjskich z 1993 r., Deklaracji moskiewskiej o ustanowieniu twórczego partnerstwa między Federacją Rosyjską i Japonią z 1998 r. - Oświadczenie prezydenta Federacji Rosyjskiej i premiera Japonii w sprawie traktatu pokojowego z 2000 r. i irkuckiego Oświadczenia prezydenta Federacji Rosyjskiej i premiera Japonii o dalszym kontynuowaniu rozmów z 2001 r." ${ }^{\text {54 }}$ Poza tym zaakcentowano w oświadczeniu poparcie członkostwa Rosji w Światowej Organizacji Handlu ${ }^{55}$.

Po powrocie do Japonii premier Koizumi oświadczył 14 stycznia 2003 r., że Rosja w pełni zrozumiała, że obustronny traktat pokojowy pomiędzy obu krajami może być podpisany po uwzględnieniu wszystkich czterech wysp, które mają wrócić do Japonii ${ }^{56}$. Tymczasem, rosyjskim komentatorom sugerowano w oświadczeniu, że z powodu japońskiej polityki dywersyfikacji źródeł pozyskiwania surowców energetycznych premier Koizumi odłożył rozwiązanie sporu terytorialnego. Jednak japońska strona zauważyła, że Koizumi podkreślił równoległe ścieżki, w tym dotyczącą negocjacji w kwestii terytorialnej, która będzie kontynuowana jednocześnie ze sprawą budowy rurociagu ${ }^{57}$. Mimo wszystko Rosjanie odnieśli wrażenie, że Japonia odłożyła na później kwestię terytorialną na rzecz dostępu do rosyjskich zasobów energetycznych. W tym przekonaniu utrzymywała ich postawa cześci „,wpływowych dyplomatów” w japońskim Ministerstwie Spraw Zagranicznych, którzy dalej myśleli o kompromisie opartym na zbliżeniu dwa plus alfa (tj. dwie wyspy mogą być zwrócone Japonii, a Rosji należy pozostawić uznanie dwóch pozostałych wysp za problem do rozwiązania) ${ }^{58} .14$ listopada 2004 r. minister spraw zagranicznych Siergiej Ławrow złożył oświadczenie, że Rosja będzie przygotowywać się do oddania dwóch wysp zgodnie z porozumieniem z $1956 \mathrm{r}$. Niemniej jednak w programie telewizyjnym stwierdził, że przed osiagnięciem kompromisu w sprawie terytorium powinien być podpisany traktat pokojowy, gdyż opinia społeczna zarówno w Rosji, jak i w Japonii powinna być przygotowana z wyprzedzeniem ${ }^{59}$.

${ }^{54}$ Sowmestnoe zajawlenie Prezidenta Rossijskoj Federacii i Prem'er-ministra Japonii o prinjatii Rossijsko-japonskogo plana dejstwij, Dokumenty, „Problemy Dalniego Wostoka” 2003, nr 2, s. 6-7.

${ }^{55}$ Ibidem.

${ }^{56}$ Keesing's Record of World Events, News Digest for January 2003, s. 45189.

${ }^{57}$ L. B u s z y ń s k i, Oil and territory..., s. 293.

${ }^{58}$ Ibidem, s. 298.

${ }^{59}$ Ibidem. 
Stanowisko ministra Ławrowa było oczywiście zgodne ze stanowiskiem prezydenta Putina, który od powoływania się na prawomocność Wspólnej deklaracji z 1956 r. przeszedł do propozycji transferu Habomai i Shikotan na rzecz Japonii. Jednak oferta rosyjska nie znalazła uznania po stronie partnera japońskiego, który oficjalnie domagał się zwrotu wszystkich czterech wysp ${ }^{60}$.

Ponadto propozycje rządu federalnego pozostające wierne Wspólnej deklaracji i transferowi dwóch spornych wysp do Japonii kontrastowały z wypowiedziami przedstawicieli władz ustawodawczych i społeczeństwa Sachalinu, potępiającymi rosyjski kompromis. Tysiące mieszkańców Sachalinu wyraziło swój sprzeciw w mass mediach, w radiu i telewizji, w licznych listach i masowych wiecach. Przedstawiciele władz ustawodawczych przyjęli rezolucję i wysłali apel do prezydenta Putina, Rady Federacji, rządu federalnego i oddziałów regionalnych legislatywy i egzekutywy w Rosji, podkreślając szkodliwe konsekwencje kupczenia suwerennością i terytorialną integralnością Rosji i zamianą ich na inwestycje zagraniczne. Zgromadzenie Ustawodawcze zaproponowało wysłanie delegacji na spotkanie z Putinem przed jego zaplanowaną wizyta w Japonii w lutym 2005 r., w celu przekonania prezydenta do zmiany zdania i zagroziło dalszymi protestami ${ }^{61}$.

Natomiast godny podkreślenia jest fakt, że w tym samym czasie administracja sachalińska pod rządami nowego gubernatora Iwana Malakowa poparła politykę rosyjskiego prezydenta. O poparciu tym świadczyło bezpośrednie odniesienie się gubernatora do Wspólnej deklaracji z 1956 r. Podkreślał on wyraźnie konieczność wypełniania przez wszystkie państwa swoich międzynarodowych zobowiązań. Co więcej, jeden z zastępców gubernatora Malakowa oświadczył, że każda decyzja podjęta przez prezydenta będzie decyzją poprawną ${ }^{62}$. Można w tym miejscu zaakcentować, że reformy poczynione wcześniej przez prezydenta Putina przyniosły wymierne efekty, tj. wzmocniły jego autorytarną władzę, a tym samym pozwoliły mu na ewentualne kompromisy terytorialne w imię szerszej polityki, wychodzącej poza ramy stosunków bilateralnych między obu państwami.

W tym czasie pojawił się jeszcze inny ważny akcent związany ze sporem terytorialnym, na który należy zwrócić uwagę. W jednym ze swoich oświadczeń prezydent Putin ujawnił, że studiował dokumenty mające istotne znaczenie dla porozumienia z 19 października 1956 r. i stwierdził, że pokazały one zamiar transferu jedynie dwóch wysp. Porozumienie zostało ratyfikowane zarówno przez parlament radziecki, jak i japoński. Było to rozbudowanie prawnego zobowiązania Rosji ${ }^{63}$. Artykuł 9 (w ustępie 1) dokumentu z 1956 r. oznaczał, że

\footnotetext{
${ }^{60}$ B. W i 11 i a m s, Federal-regional relations..., s. 2.

${ }^{61}$ Ibidem.

${ }^{62}$ Ibidem.

${ }^{63}$ L. B u s z y ń s k i, Oil and territory..., s. 298.
} 
Związek Radziecki przekaże, a nie zwróci, dwie wyspy. Różnica ta została uznana za poważną. Ponadto zaznaczono, że w dokumencie nie ma sformułowań o traktacie pokojowym jako zasadniczym celu. W tym miejscu prezydent Putin świadomie zdaje się zapominać o przyczynie niepodpisania w 1956 r. traktatu pokojowego między Związkiem Radzieckim a Japonią. Głównym powodem był właśnie brak ostatecznego rozwiązania sporu terytorialnego i zapewnienie ustne władz radzieckich wobec ówczesnego japońskiego ministra spraw zagranicznych Matsumoto, że nawet po normalizacji stosunków dwustronnych będą kontynuowane negocjacje dotyczące zawarcia traktatu pokojowego, obejmujące kwestie terytorialne, o czym wspomniałem wcześniej.

Ponadto pojawił się także kolejny akcent w sporze. Rosyjskie Ministerstwo Spraw Zagranicznych dowodziło, że porozumienie z 1956 r. zostało właściwie unieważnione przez Związek Radziecki 27 stycznia 1960 r. po japońskim podpisaniu Traktatu o Wzajemnej Współpracy i Bezpieczeństwie ze Stanami Zjednoczonymi z 19 stycznia tego roku ${ }^{64}$. Niemniej jednak ówczesne stanowisko radzieckie wyglądało inaczej. Związek Radziecki nie unieważnił - ani wówczas, ani później - Wspólnej deklaracji z 1956 r., natomiast w związku z powyższym traktatem amerykańsko-japońskim władze radzieckie w memorandum wręczonym 27 stycznia 1960 r. ambasadorowi japońskiemu w Moskwie, stwierdziły m.in., że „,...] rząd radziecki uważa za rzecz konieczną oświadczyć, że wyspy Habomai i Shikotan zostaną przekazane Japonii jedynie pod warunkiem wycofania $\mathrm{z}$ Japonii wszystkich obcych wojsk i podpisania traktatu pokojowego pomiędzy Japonią i ZSRR tak jak to przewidziano we Wspólnej deklaracji ZSRR i Japonii z dnia 19 października 1956 r." ${ }^{\text {"65 }}$ Oświadczenie radzieckie zostało uznane przez ówczesny rząd japoński za jednostronną próbę zmiany tekstu Wspólnej deklaracji oraz za „mieszanie się w wewnętrzne sprawy Japonii”, ${ }^{\prime \prime}$.

Jednak premier Koizumi, odpowiadając na argumenty prezydenta Putina, konsekwentnie upierał się przy swojej wersji, twierdząc, że zwrot wszystkich wysp jest nieodłączną częścią porozumienia z 1956 r. Powtórzył swoje stanowisko podczas spotkania z rosyjskim prezydentem 23 listopada 2004 r. w Santiago, gdzie odbywał się szczyt APEC ${ }^{67}$. Partner rosyjski upierał się nadal przy swojej ofercie, która w Japonii została uznana za niekorzystną w porównaniu z oferta dla Chin $^{68}$.

${ }^{64}$ Ibidem.

${ }^{65}$ Memorandum from the Soviet Union to Japan, 27 January 1960, [w:] Documents on American Foreign Relations, Oxford University Press, London-New York-Toronto 1964; Memorandum, „Nowoje Wremja” (wkladka - dokumenty), 29 I 1960; Keesing's Contemporary Archives, 2-9 IV 1960, Vol. 12, s. 17342.

${ }^{66}$ Ibidem, s. 17342.

${ }^{67}$ L. B u s z y ń s k i, Oil and territory..., s. 298.

${ }^{68}$ Ibidem. 
7 lutego 2005 r. Japonia uczciła 150 rocznicę japońsko-rosyjskiego traktatu o przyjaźni, organizując wiec poparcia na rzecz powrotu spornych wysp ${ }^{69}$. Należy podkreślić, że od 25 lat, tj. od 1981 r., dzień 7 lutego jest uroczyście obchodzony w Japonii, jako dzień Terytoriów Północnych ${ }^{70}$. Jednak rocznica 150-lecia nawiązania stosunków dyplomatycznych i ich uroczyste obchody w Japonii nie przyniosły przełomu w dotychczasowym sporze. Obaj przywódcy złożyli sobie wzajemne wizyty: premier Koizumi przybył 10 maja 2005 r. do Moskwy, a prezydent Putin w dniach 20-22 listopada tego roku - w Tokio. Na obu szczytach obaj przywódcy zobowiązali się zarówno do aktywnego kontynuowania przygotowań dotyczących traktatu pokojowego, jak i współpracy w wielu dziedzinach ${ }^{71}$. Problem tkwi jednak w tym, że konsekwentnie trzymają się swojego stanowiska ${ }^{72}$, u podłoża którego leżą odmienne oczekiwania.

Ze strony rosyjskiej pojawia się oczekiwanie, że rozwój silnych więzi gospodarczych $\mathrm{z}$ partnerem japońskim, a zwłaszcza jego zapotrzebowanie na rosyjską ropę naftową i energię, wpłynie na „osłabienie” stanowiska partnera. Należy podkreślić, że dla Japonii w stosunkach z Rosją liczą się przede wszystkim surowce energetyczne. Jeśli jednak chodzi o ropę naftową, to, jak podkreślali eksperci japońscy, zbudowanie rurociągu ropy naftowej Angarsk-Nachodka zredukuje uzależnienie Japonii od tego surowca ze Środkowego Wschodu jedynie o $10 \%^{73}$. Japonia nie będzie zatem na tyle uzależniona od strony rosyjskiej, aby iść na jakiekolwiek ustępstwa. Jednakże z kolei Japonia liczy na ustępstwo terytorialne ze strony Rosji w zamian za jej olbrzymią pomoc gospodarczą, szczególnie, jeśli chodzi o inwestycje bezpośrednie, których potrzebuje rosyjska gospodarka. Dotychczasowe inwestycje japońskie są jednak niezwykle skromne. Na początku XXI w. przekraczały nieznacznie $1 \%$ wszystkich zagranicznych inwestycji w Rosji ${ }^{74}$. Środowisko inwestycyjne w Rosji jest wyjątkowo niepewne. Ponadto, co jest istotne, wartość połowów rybaków

${ }^{69}$ Keesing's Record of World Events, New Digest for February 2005, s. 46470.

${ }^{70} \mathrm{Na}$ przełomie lat siedemdziesiątych i osiemdziesiątych XX w. w Japonii była rozwijana kampania na rzecz powrotu Terytoriów Północnych. Uwieńczona została decyzją rządu japońskiego z 6 stycznia 1981 r. o ogłoszeniu 7 lutego dniem Terytoriów Północnych. Zob.: „The Japan Times Weekly", 14 and 25 February 1981; Japan's Northern Territories, Ministry of Foreign Affairs, Tokyo 1991, s. 13.

${ }^{71}$ MOFA: Visit by Prime Minister Junichiro Koizumi to Russia (Japan-Russia Summit Meeting), [w:] http:/www.mofa.go.jp/region/Europe/Russia/pmv0505.html (stan z 10.11.2006); Visit to Japan of His Excellency, Mr. Vladmiri Vladimirovich Putin, President of the Russian Federation and Mrs. Putina, htpp://www.mofa.go.jp/announce/event2005/11/1115.html (stan z 19.11.2006).

72 Japan-Russia Relations (1). The Northern Territories Issue and Peace Treaty Negotiation, „Diplomatic Bluebook” 2006, s. 95-96, http://www.mofa.go.jp/region/europe/russia.

${ }^{73}$ M. A. S mith, Russo-Japanese Relations, Conflict Studies Research Centre, Defence Academy of the United Kingdom, October 2003, F84, s. 10.

${ }^{74}$ Ibidem. 
rosyjskich na wodach otaczających sporne wyspy jest mierzona w dziesiątkach mln USD, nie są oni zatem zainteresowani nieograniczonym dostępem do tych wód rybaków japońskich. Japonia również powinna pamiętać o tym, że Rosja rozwija stosunki handlowe i gospodarcze także $\mathrm{z}$ wielu innymi atrakcyjnymi partnerami.

Reasumując, niewątpliwie w dającej się przewidzieć perspektywie Rosja zachowa swoją suwerenność nad spornymi wyspami i żaden z innych wariantów rozwiązania tego sporu raczej nie wchodzi w rachubę. Japonia nie zgodzi się na transfer wysp Habomai i Shikotan, a z kolei Rosja nie dopuści do transferu wszystkich czterech wysp. Ponadto niezależność, wysp od którejkolwiek ze stron sporu jest wykluczona. Trudna do wyobrażenia jest wspólna suwerenność nad nimi, podobnie jak i sprzedaż z zachowaniem prawa użytkowania. Rozwiązaniem mogłoby być np. wejście Rosyjskiego Dalekiego Wschodu (wraz ze spornymi wyspami) do jednej z azjatyckich stref wolnego handlu, co pozwoliłoby, z jednej strony, zachować twarz obu partnerom, a z drugiej - obniżyłoby poziom emocji z nimi związanych. Oczywiście Japonia uzyskałaby na mocy tego rozwiązania wymierne korzyści, jednak cel polityczny, jakim jest rozciągnięcie nad nimi własnej suwerenności, i tak nie zostałby zrealizowany.

Pytaniem otwartym pozostaje, czy jakiś polityk przetnie ten węzeł gordyjski. Na razie władze rosyjskie, podobnie jak wcześniej radzieckie, liczą na to, że upływ czasu rozwiąże problem wysp Habomai, Shikotan, Kunashir i Iturup (Etorofu). 